\title{
DINAMIKA MADRASAH DINIYAH: \\ Suatu Tinjauan Historis
}

\author{
Nuriyatun Nizah \\ LPPG (Lembaga Peningkatan Profesi Guru), \\ Jawa Tengah, Indonesia \\ nuriyatunnizah@gmail.com
}

\begin{abstract}
Abstrak
Kajian ini bertujuan untuk mengeksplorasi madrasah diniyah dari tinjauan historis. penelitian ini adalah dengan pendekatan kepustakaan. Madrasah Diniyah memberikan kesadaran untuk Masyarakat Islam tentang keberadaan Pendidikan Agama. Dalam perkembangannya, telah menyebabkan pembaharuan Pendidikan Islam. Pada Madrasah tahap berikutnya diniyah masih telah menerima pengakuan dari pemerintah sebagai bagian dari sistem pendidikan nasional di Indonesia. Ini juga memiliki tingkat pendidikan seperti pendidikan dasar yang disebut madrasah diniyah ula atau awaliyah, sekunder pendidikan disebut diniyah wustho dan ulya terdiri dari tiga tingkat, yang setara dengan tingkat MTs dan MA. Madrasah diniyah adalah karakteristik pendidikan Islam yang memiliki dinamika yang signifikan sejak awal keberadaannya.
\end{abstract}

Kata kunci: madrasah, sejarah, pengembangan

\begin{abstract}
THE DYNAMICS OF MADRASAH DINIYAH: A HISTORICAL REVIEW. Madrasah Diniyah provides awareness to Islamic Society on the existence of Religious Education. In its development, it has led to the renewal of Islamic Education. At a later stage Madrasah diniyah has still been receiving recognition from the government as part of the
\end{abstract}


Nuriyatun Nizah

national education system in Indonesia. It also has education levels such as primary education called madrassas Diniyah ula or awaliyah, secondary education called diniyah wustho and Ulya consist of three levels, which are equivalent to the level of MTs and MA. The Madrasah diniyah is the characteristic of Islamic education which has significant dynamics since the beginning of its existence.

Keywords: madrasah, history, development

\section{A. Pendahuluan}

Cikal bakal pendidikan Islam di Indonesia dimulai dengan keberaadaan masjid, pesantren, Surau (langgar) dan madrasah. Seiring dengan perkembangan zaman, maka fungsi dari lembagalembaga tersebut mengalami pergeseran. Mungkin hanya pesantren dan madrasah saja yang sampai hari ini eksistensinya masih berfungsi sebagai lembaga pendidikan Islam. Membincang tentang madrasah dalam konteks Keindonesiaan adalah lembaga pendidikan Islam yang lahir dari kebutuhan masyarakat oleh masyarakat dan untuk masyarakat.

Keberadaan Madrasah diniyah dilatarbelakangi adanya keinginan dari masyarakat Islam untuk belajar secara seimbang antara ilmu agama dan ilmu Pengetahuan umum. Madrasah di Indonesia memiliki sejarah yang cukup panjang, eksistensinya bermula pada abad ke-20. Dalam lintasan sejarah, eksistensi madrasah tidak lepas karena adanya semangat pembaharuan pendidikan yang dipengaruhi oleh Islam di Timur tengah dan merupakan respon terhadap kebijakan pendidikan dari pemerintahan Hindia Belanda yang telah mengembangkan pendidikan dengan sistem persekolahan terlebih dahulu.

Eksistensi madrasah dari masa ke masa semakin diakui oleh pemerintah dan masyarakat. Sebelum lahirnya UU Sisdiknas No. 20 tahun 2003, madrsah Diniyah (MADIN) dikenal sebagai Madrasah (Haidar Daulay, 2009: 21). Madrasah memiliki karakteristik tersendiri ditinjau dari berbagai aspek. Madrasah selalu mengikuti perkembagan zaman, sehingga memunculkan model-model madrasah dengan segala kekhasannya. Bahkan pemerintah mulai memperhatikan perkembangan madrasah dengan memberikan pengakuan dan fasilitas bagi madrasah. Jenjang pendidikan di Madrasah dimulai dari 
pendidikan dasar, menengah dan atas atau disebut dengan madrasah ibtidaiyah, madrasah tsanawiyah dan madrasah aliyah. Sedangkan madrasah "diniyah" dalam struktur pendidikan Islam di Indonesia masuk dalam kategori pendidikan non formal yang merupakan kelanjutan dari eksistensi madrasah pada awal kemunculannya. Dalam tulisan ini membahas tentang ekistensi madarasah diniyah (keagamaan) dan dinamikanya di Indonesia.

\section{B. Pembahasan}

\section{Sekilas Tentang Sejarah Madrasah di Indonesia}

Urgensi keberadaan madrasah memberikan kesadaran Masyarakat Islam akan pentingnya pendidikan agama. Dalam perkembangannya telah membawa ke arah pembaharuan dalam Pendidikan. Pada awal mulanya pendidikan Islam dilaksanakan dimasjid yang sejak awal kelahirannya berfungsi selain sebagai tempat beribadah tetapi juga sebagai tempat mencari dan mengasah ilmu. Ditinjau dari pelaksanaan pembelajarannya masih sederhana. Yang terpenting adalah memotivasi umat Islam untuk selalu mau menuntut ilmu (belajar). Dalam tradisi masyarakat Islam di Indonesia tempat pendidikan disesuaikan dengan situasi kondisinya. Keberadaan Surau (langgar) yang berfungsi sebagai tempat Ibadah juga berperan sebagai tempat untuk belajar. Begitu seterusnya sampai pada masa munculnya ide untuk membentuk sebuah sekolah -madrasah- yang memang dikhususkan untuk memenuhi kebutuhan umat Islam.

Model Pendidikan Islam yang diadakan di surau-surau tidak diselenggarakan dengan menggunakan kelas serta tidak dilengkapi bangku, meja dan papan tulis. Siswa belajar dengan "lesehan" saja. Seiring dengan perkembangan zaman, maka model pendidikan yang bermula "lesehan" lambat laun berubah dengan menggunakan sistem kelas.

Secara historis perkembangan madrasah dengan model kelasikal di Indonesia dimulai dengan munculnya madrasah "Sekolah Adabiyah (Adabiyah School)” di Padang (Minangkabau). Madrasah ini didirikan oleh Almarhum Syekh Abdullah Ahmad pada tahun 1909. Adabiyah itu hidup sebagai madrasah (sekolah agama) sampai tahun 1914. Pada tahun 1915 diubah menjadi H.I.S. Adabiyah. 
Pada akhirnya H.I.S Adabiyah itu telah menjadi Sekolah Rakyat dan S.M.P. Selanjutnya pada tahun 1909 almarhum Syekh H.M Thaib Umar yang mendirikan sekolah Agama di Batu Sangkar, akan tetapi tidak dapat bertahan. Kemudian pada tahun 1910 Syekh H.M Thaib Umar mendirikan sekolah agama di sungayang (daerah batu sangkar) dengan nama Madras School (Sekolah Agama).

Pada awalnya di Madras School hanya diadakan satu kelas saja, tujuannya adalah sebagai tangga untuk mengaji kitab-kitab besar dengan sistem halaqoh. Pada tahun 1913 Madras School itu terpaksa ditutup, karena kekurangan tempat. Kemudian dibangun kembali oleh Mahmud Yunus pada tahun 1918 dan berjalan dengan lancar. Pada tahun 1923 ditukar namanya dengan Al-Jamiah Islamiyah pada tahun 1931 dan masih hidup sampai sekarang dengan nama AlDidayah Islamiyah dan S.M.P.I/P.G.A.P.1 (Yunus,1979: 30) dalam Muhammad Iqbal Basry.

Pada era berikutnya, tahun 1915 Zainuddin Labai al Yunusi mendirikan Diniyah School (Madrasah Diniyah) di padang panjang. Bagi masyarakat Minangkabau madrasah ini menjadi perhatian yang besar. Madrasah Diniyah padang panjang merupakan cikal bakal dalam perkembangan madrasah-madrasah di berbagai kota dan desa minang kabau khususnya Yunus dalam Haidar Daulay (2009:33). Perkembangan maadrasah Diniyah di era Zainudin Labai al Yunusy berkembang cukup pesat sampai pada cabang-cabang di nagari. Ketika tahun1922 didirikan perkumpulan murid-murid Diniah School (P.M.D.S) berpusat di Pandang Panjang. Selanjutnya, muncul Madrasah Diniyah Putri yang dipelopori oleh Rangkayo Rahmah ElYunusiah tahun 1923 (Maksum, 1999: 104)

\section{Lembaga Pendidikan Islam di Indonesia}

Kata "lembaga" sebagaimana dalam Kamus Besar Bahasa Indonesia (1999: 579-580) berarti badan atau organisasi yang tujuannya melakukan suatu penyelidikan keilmuan atau melakukan usaha. Menurut Omar Muhammad al Thoumi al-Syaibani, dalam Toto Suharto (2005: 102), pendidikan Islam adalah sebagai proses tingkah laku individu dalam kehidupan pribadinya atau kehidupan kemasyarakatannya dan alam sekitarnya melalui interaksi yang dilakukan individu tersebut. 
H.M. Arifin menyebutkan, bahwa tujuan proses pendidikan Islam adalah idealitas (cita-cita) yang mengandung nilai-nilai Islam yang akan dicapai dalam proses kependidikan yang berdasarkan agama ajaran Islam secara bertahap. Berdasarkan tujuan tersebut maka pendidikan Islam memiliki pengertian sebuah proses yang dilakukan manusia seutuhnya, beriman, dan bertakwa kepada Tuhan serta mampu mewujudkan eksistnsinya sebagai khalifah Allah di muka bumi, yang berdasarkan ajaran dan sunnah, maka tujuan dalam konteks ini berarti trciptanya insan-insan kamil setelah proses pendidikan berakhir. (Arief, 2002: 51-16). Jadi yang dimaksud dengan lembaga pendidikan Islam adalah lembaga pendidikan atau tempat berlangsungnya proses pendidikan yang dilakukan dengan tujuan untuk mengubah tingkah laku individu (Suharto, 2005: 105)

Secara garis besar ada tiga jenis lembaga pendidikan Islam, yaitu; lembaga pendidikan formal, lembaga pendidikan informal, dan lembaga pendidikan non formal. Pertama, lembaga pendidikan formal atau lebih dikenal dengan "sekolah/madrasah atau sejenisnya" adalah lembaga pendidikan yang merupakan kelanjutan dari pendidikan di dalam keluarga. Sekolah atau madrasah dan yang sejenisnya berfungsi sebagai pembantu keluarga dalam hal ini adalah orang tua dalam mendidik anak. Tugas pendidikan kemudian dibebankan kepada pengelola lembaga pendidikan (sekolah atau madrasah).

Dalam undang-undang Sistem Pendidikan Nasional, madrasah termasuk kategori lembaga pendidikan keagamaan yang peran dan fungsinya sama dengan sekolah-sekolah pada umumnya. Ditinjau dari aspek kurikulum yang digunakan, dalam kurikulum madrasah memuat semua kurikulum sekolah yang ada di bawah naungan depertemen pendiidkan nasional.

Ditinjau dari aspek materi yang diajarkan, madrasah dapat disebut dengangan sekolah plus. Siswa dapat pengetahuan agama yang lebih dibanding siswa-siswa yang sebelajar di sekolah. Penguasaan materi keagamaan lebih dibanding siswa yang belajar di sekolah "umum" dan lebih mendalam. Hal inilah yang menjadi daya tarik para orang tua untuk memasukkan naka-anaknya ke madrasah (Khozin, 2006:78)

Kedua, lembaga pendidikan informal yaitu pendidikan 
keluarga. Karena lembaga pendidikan pertama dan utama adalah keluarga. Pendidikan dalam keluarga menjadi tanggungjawab penuh orang tua. Orang tua meletakkan dasar-dasar kepribadian yang baik pada diri anak-anak dari usia dini. Keberhasilan pendidikaan yang diterapkan dalam keluarga tergantung pada setiap orang tua dalam menerapkan pendidikan bagi anak-anaknya. Pembentukan kepribadian anak dimulai dari pendidikan keluarga. Rasulullah bersabda: "Sesungguhnya setiap anak dilahirkan dalam keadaan fitrah, maka sesungguhnya kedua orang tuanyalah yang menjadikan majusi, Yahudi atau nasrani. Dari hadits ini menunjukkan orang tua memiliki tanggungjawab yang besar dalam membentuk kepribadian anak (Suharto, 2005: 105).

Namun seiring perkembangan zaman, dalam mendidik anak di rumah, terkadang tidak maaksimal karena orang tua disibukkan dengan pekerjaan atau kegiatan mencari nafkah. Oleh karena itu pendidikan anak selanjutnya diserahkan kepada lembaga sekolah, namun dalam hal ini orang tua tetap memantau keberhasilan pendidikan anak-anaknya. Pada dasarnya penyerahan anak kepada lembaga sekolah bukan berarti orang tua lepas tanggung jawabnya sebagai pendidik yang pertama dan utama, tetapi orang tua masih memiliki saham dalam membina dan mendidik anak (Suharto, 2005: 167)

Ketiga, Lembaga pendidikan non formal biasanya adalah lembaga pendidikan yang lahir dari ide masyarakat dan untuk kepentingan masyarakat yang tidak formal, contoh pengajianpengajian. Lembaga pendidikan yang dimaksud yaitu lembaga pendidikan yang ada di dalam masyarakat, baik berupa pengajian, majlis ta'lim dan madrasah diniyah. (Suharto, 2005: 103). Dalam definisi lain disebutkan bahwa majlis ta'lim adalah lembaga swadaya masyarakat yang keberadaannya didasarkan pada keinginan untuk membagun masyarakata madani (Hasbullah, 1999: 94). Sedangkan pendidikan diniyah non formal diselenggarakan dalam bentuk pengajian kitab, majlis ta'lim, pendidikan al-Quran, diniyah ta'limiyah atau dalam bentuk lain yang sejenis. (PP No 55 pasal 15-16 tahun 2007, Tentang Pendidikan Agama dan Kegamaan) 


\section{Karakteteristik Madrasah Diniyah}

Sistem belajar di madrasah Diniyah merupakan evolusi dari sistem belajar yang dilaksanakan di pesantren salafiyah, karena pada awalnya dalam penyelenggaraan pendidikannya dilakukan dengan cara tradisonal. Adapun cirri khas untuk mempertahankan tradisi pesantren adalah mempertahankan paradigma penguasaan "kitab kuning” (Haedari, 2006: 18). Sementara pada awalnya, sistem pembelajarannya menggunakan metode "halaqoh", yaitu model belajar di mana guru duduk di lantai di kelilingi oleh santri (murid), dengan mendengarkan penyampaian ilmu-ilmu agama. Namun model halaqoh tersebut mengalami pergeseran seiring dengan perkembangan zaman. Adapun perubahan yang dilakukan dengan dari sistem halaqoh ke sistem klasikal. Perubahan model tersebut berdampak pada respon masyarakat (Islam) dalam perkembangan pendidikan Islam di Indonesia.

Bergesernya sistem "halaqoh" yang berlaku di pesantren ke sistem klasikal di Madrasah memberikan situasi baru dalam pembelajaran. Pendidikan agama di madrasah Diniyah digolongkan pendidikan keagamaan yang tertutup terhadap pengetahuan umum, sehingga model pendidikan yang seperti ini di sebut dengan "sekolah agama atau sekolah diniyah" (Yusuf, 2006: 277).

Sehubungan dengan perkembangan Madrasah diniyah di masyarakat, maka untuk memudahkan pembinaan dan bimbingan Kementerian Agama RI (Depag RI, 2000:10), pemerintah menetapkan peraturan tentang jenis-jenis Madrasah Diniyah yang diatur dalam Peraturan menteri Agama RI Nomor 13 tahun1964 yang antara lain dijelaskan:

a. Madrasah Diniyah ialah lembaga pendidikan yang memberikan pendidikan dan pengajaran secara klasikal dalam pengetahuan Agama Islam kepada pelajar bersamasama sedikitnya berjumlah 10 (sepuluh) orang atau lebih diantara anak-anak yang berusia 7 (tujuh) sampai dengan 18 (delapan belas) tahun.

b. Pendidikan dan pengajaran (pada madrasah Diniyah) selain bertujuan untuk memberi tambahan pengetahuan agama kepada pelajar-pelajar yang merasa kurang menerima pelajaran agama di sekolah-sekolah umum. 
c. Madrasah diniyah ada tiga tingkatan yakni; diniyah awaliyah, diniyah wustho, dan diniyah ulya.

Dengan diberlakukannya undang-undang nomor 20 tahun 1989 tentang sistem pendidikan nasional, maka untuk mengatur lembaga pendidikan yang beragam di Indonesia dikeluarkan pula peraturan pemerintah yaitu hasil pendidikan non formal dapat dihargai setara dengan hasil program pendidikan formal setelah melalui proses penyetaraan oleh lembaga yang ditunjuk oleh pemerintah ataupemerintah daerah dengn mengacu pada standar nasional pendidikan.

Dasar penyelenggaraan pendidikan madrasah diniyah dalam konteks Sistem Pendidikan Nasional, baik pendidikan diniyah klasikal maupun pendidikan diniyah takmiliyah termasuk kategori pendidikan nonformal. Semua aktivitas pendidikan termasuk pendidikan diniyah merupakan sub-sistem dari sistem pendidikan nasional. Apabila pendidikan diniyah akan ditempatkan sebagai pendidikan formal, maka perlu diperhatikan dasar-dasar hukum sebagai berikut:

a. Undang-Undang RI Nomor 20 tahun 2003 tentang Sistem Pendidikan Nasional.

b. Undang-Undang RI Nomor 14 Tahun 2005 Tentang Guru dan Dosen

c. Peraturan Pemerintah RI Nomor 19 Tahun 2005 Tentang Standar Nasional Pendidikan

d. Peraturan Pemerintah RI Nomor 55 Tahun 2007 Tentang Pendidikan Agama dan Pendidikan Keagamaan

e. Peraturan Pemerintah RI Nomor 74 Tahun 2008 Tentang Guru

f. . Peraturan Menteri Pendidikan Nasional RI Nomor 72 Tahun 2006 Tentang Standar Isi Untuk Satuan Pendidikan Dasar dan Menengah

g. Peraturan Menteri Pendidikan Nomor 23 Tahun 2006 Tentang Kompetensi Lulusan Untuk Satuan Pendidikan Dasar dan Menengah

h. . Peraturan Menteri Pendidikan Nasional RI Nomor 24 Tahun 2006 Tentang Pelaksanaan Pendidikan No. 22 dan 23 Tahun 2006 
i. . Peraturan Menteri Pendidikan Nasional RI Nomor 16 Tahun 2007 Tentang Standar Kualifikasi Akademik dan Kompetensi Guru.

Dalam perkembangan pendidikan Islam di Indonesia Madrasah diniyah sejak awal kemunculannya selalu mengalami pergeseran. Pergeseran yang dimaksud adalah bahwa dalam paradigma pendidikan nasional Indonesia, sistem Madrasah Salafiyah (diniyah) belum mendapatkan pengakuan dari pemerintah terutama yang berkaitan dengan pengakuan kelulusan siswa. Hal ini tentunya berdampak negatif bagi para lulusan untuk melanjutkan ke pendidikan umum yang sederajat.

Oleh karena itu ada upaya memecahkan persoalan ini, maka sejak tanggal 24 maret 1975, madrasah memiliki dasar juridis yang kuat dengan lahirnya Surat Keputusan Bersama Tiga Menteri (SKB); Menteri Agama, Menteri Pendidikan dan Kebudayaan, dan Menteri Dalam Negeri tahun 1975 yang memiliki tujuan untuk meningkatkan mutu pendidikan pada Madrasah dengan cara melakukan perubahan kurikulum Madrasah yang berbanding 30\% ilmu agama dan $70 \%$ pengetahuan umum. Dengan demikian secara legal dan formal ada pengakuan dari pemerintah bahwa ijazah dan lulusan madrasah memiliki nilai yang sama dengan ijazah dan lulusan sekolah umum yang setingkat.

Dengan diberlakukannya SKB 3 Menteri tersebut maka terjadi pula penggeseran dan perubahan dalam skala masif (besarbesaran) di lingkungan madrasah diniyah baik yang ada di dalam dan di luar pondok pesantren. Perubahan yang terjadi adalah munculnya Madrasah Ibtidaiyah, Tsanawiyah, dan Aliyah. Disatu sisi perubahan ini dapat bermanfaat bagi peserta didik karena ada pengakuan bagi lulusannya.

Akan tetapi disisi lain sangat merugikan Pondok Pesantren maupun Madrasah Diniyah yang memang khusus pada pendalaman ilmu-ilmu keislaman. Sebab, dalam jangka panjang, karakteristik kedua lembaga pendidikan agama tersebut, seperti kajian kitab-kitab kuning yang menjadi sumber ajaran-ajaran Islam mulai tidak diminati oleh para santri, dan posisi Madrasah Diniyah menjadi pelengkap (takmiliyah/sekunder). 
Bila ditinjau dari aspek tipologinya lahirnya lembaga pendidikan "mdrasah diniyah" ditinjau dari sisi historisitasnya merupakan kelanjutan dari sistem pendidikan pesantren gaya lama, yang dimodifikasi menurut model penyelenggaraan sekolah-sekolah umum dengan nmodel klasikal. Pada awal berdirinya -sekitar abad ke 19 dan awal abad ke-20 "madrasah diniyah" dalam penyelenggaraan pendidikanya disamping memberikan ilmu pengetahuan agama, juga diberikan ilmu pengetahuan umum. Hal ini sesuai dengan falsafah Negara -Indonesia-, pendidikan madrasah adalah ajaran agama Islam, falsafah Negara Pancasila dan UUD 1945 (Abdushoma, 2006: 90-91).

Perkembangan madrasah di Indonesia tidak lepas dari perkembagan ide-ide pembaharuan yang lahir dari kalangan tokoh-tokoh pendidikan Islam di Indonesia. Perbahan paradigma pemikiaran tentang pendidikan Islam sudah mulai muncul pada awala abad ke-20 dengan masuknya ide-ide pembaharuan dalam pendidikan Islam.

Menurut Haidar Putra Daulay (2001:63) ada beberapa hal yang melatarbelakangi lahirnya ide-ide pembaharuan tersebut, diantaranya:

1. Adanya kecenderungan umat Islam untuk kembali kepada al-Quran dan al-Hadits. Kecenderungan ini dijadikan titik tolak dalam menilai kebiasaan agama dan kebudayaan yang ada.

2. Timbulnya dorongan perlawanan nasional terhadap penguasa colonial Belanda.

3. Usaha yang kuat dari orang-orang Islam untuk memperkuat organisasinya dibidang sosial, ekonomi, baik untuk kepentingan mereka sendiri maupun untuk kepentingan masyarakat.

4. Adanya pembaharuan pendidikan Islam sehingga cukup banyak orang dan organisasi Islam tidak puas dengan metode tradisional dalam mempelajari al-Quran dan studi Islam pada awal abad ke- 20 berusaha untuk memperbaiki pendidikan Islam baik dari segi metode maupun isi.

Lembaga pendidikan formal berbasis pendidikan agama 
dalam konteks ke-Indonesiaan sebagaimana dijelaskan oleh Nur Uhbiyati (2005: 233-239) dalam bukunya Ilmu Pendidikan Islam terdiri dari enam jenjang sebgai berikut: 1) Rudlatul Athfal I (Bustanul athfal), 2) Madrasah Ibtidaiyah (MI=SD), 3) Madrasah Tsanawiyah (Mts=SMP), 4)Madrasah Aliyah(MA=SMA/SMK), dan al-Jami'ah (IAIN; Institut Agama Islam Negeri).

Hubungan pesantren dengan madrasah diniyah sangat erat sekali bila ditinjau dari aspek kegiatan pembelajarannya. Dalam sejarah pendidikan keagamaan di Indonesia, paling tidak ada tiga institusi pendidikan nasional. Untuk pendidikan berbasis Islam terdiri dari pesantren dan madrasah. Sedangkan untuk pendidikan Kristen adalah zending pada zaman Hindia Belanda. (Ishom El Saha, Dinamika Madrasah Diniyah di Indonesia Menelusuri AkarSejarah Pendidikan Formal, 39-43). Ketiga lembaga pendidikan keagamaan tersebut, mengalami dinamika yang cukup signifikan. Untuk pesanteran tetap eksis sampai hari ini dengan berbagai modelnya, sedangkan madrasah, dalam hal ini madrasah Diniyah, dalam perkembangannya mengalami pasang surut. Sesungguhnya madrasah Diniyah merupakan institusi pendidikan keagamaan yang berbeda dari pesantren, surau maupun halaqoh.

Sistem pendidikan di Madrasah Diniyah terintegrasi dengan model pendidikan di pesantren. Hal ini dilakukan supaya nilai-nilai pendidikan agama "Islam" tidak tercerabut tetapi tetap ada dalam proses pembelajaran, meskipun pola pembelajaran di pesantren terkadang sangat berbeda dengan pola di Madrasah diniyah. Dari usaha diatas dapat dihasilkan berupa usaha pesantren mulai berbenah dan mencoba mengintegrasikan model pembelajarannya di madrasah, sehingga di pesantren era sekarang banyak yang menggunakan sistem pembelajaran sistem klasikal.

Fenomena inilah yang melatarbelakangi banyak pesantren mulai membuka madrasah diniyah. Misalnya pesantren Tebu Ireng Jombang (KH Hayim Asy'ari), Pesantren al-Munawir Yogyakarta, Pesantren Modern Gontor Ponorogo, dan lain-lain. sehingga pada perkembangannya banyak pesantren-pesantren di Indonesia yang mengkolaborasikan sistem pesantren dan madrasah. 
Nuriyatun Nizah

\section{Kondisi Objektif Madrasah Diniyah di Indonesia}

Fenomena kegiatan pembelajaran madrasah diniyah dilakukan pada sore hari antara pukul 14.00-15.00. atau dalam bahasa orang awam disebut dengan istilah "sekolah sore" atau "sekolah arab". Ada tiga alas an yang mendasari waktu sore dipilih sebagai waktu yang tepat untuk belajar, yaitu: Pertama, faktor sumber daya alam yang melimpah dengan sumber daya manusia yang mini. Kedua, sebagai bias kolonialisme yang telah memperlakukan diskriminasi kepada masyarakat pribumi dengan cara mempersulit hak ajar. Masyarakat di awal-awal kemerdekaan masih kurang menyadari arti pendidikan untuk anak-anaknya. Ketiga, madrasah sore dimaksudkan untuk mengimbangi pendidikan umum yang diikuti anak-anak di sekolah rakyat (SR) di waktu pagi. Mobilisasi orang tua dan anak-anak yang telah belajar di SR agar mau belajar di madrasah diniyah sore bukanlah pekerjaan mudah. Untuk mensiasati hal tersebut maka para ulama/kyai lebih banyak mensosialisasikan madrasah diniyah dengan sebutan SRI (Sekolah Rakyat Islam).

Sampai sekarang madrasah diniyah masih mempertahankan tradisi waktu yang digunakan untuk belajar yaitu sore dengan pertimbangan untuk memberikan tambahan wawasan keagamaan siswa yang sekolah pagi (SD/MI, MTs/SMP, MA/SMA) yang notabenenya hanya mendapatkan pengetahuan agama hanya sedikit.

Beberapa aspek yang masih memperkokoh eksistensi madrasah diniyah adalah sebagai berikut:

\section{a. Aspek kelembagaan}

Secara legal formal keberadaan Madrasah Diniyah sebagai satuan pendidikan keagamaan (Islam) yang telah diakui dalam UU Sistem Pendidikan Nasional nomor 20/2003 maupun peraturan pemerintah (PP No 55 Tahun 2003). Keberadaannya efektif untuk menambah pengetahuan agama para anak didiknya, yang tidak diperoleh di bangku sekolah formal.

Diniyah, sebagai salah satu jenis /satuan pendidikan keagamaan yang memberikan pendidikan umum dengan tetap mempertahankan ciri khasnya sebagai lembaga pendidikan Islam. Pelajaran diniyah meliputi pelajaran al-Quran, Hadits, Fiqh, Akhlak, sejarah Islam, dan bahasa Arab. Dalam penyelenggaraannya, Madrasah 
diniyah menggunakan pendekatan klasikal. Namun Madin memiliki wariasi kelembagaan cukup banyak; ada yang diselenggarakan oleh pesantren, masyarakat ( $t a^{\prime}$ mir masjid), perorangan atau yayasan dan organisasi (sosial-keagamaan). Dalam kategori sistem pendidikan nasional Madrasah Diniyah ada yang termasuk dalam pendidikan jalur formal dan jalur nonformal.

Madrasah diniyah pada jenjang pendidikan dasar disebut dengan madrasah Diniyah ula atau awaliyah yang masa belajarnya sampai kelas enam (enam tahun) seperti MAdrasah Ibtidaiyah. Sedangkan jejang pendidikan tingkat menengah disebut dengan diniyah wustho dan ulya terdiri dari tiga tingkatan atau setara dengan jenjang MTs dan MA. Namun untuk jenjang yang ditetapkan di setiap tempat tidak sama ada empat tahun ada yang 6 tahun fleksibel. Tata aturan mulai dari sistem perekrutan siswa, guru bahkan sampai pada pelaksanaan pembelajaran terkadang tidak mengikuti aturan yang ketat. Jika Madrasah Diniyah di luar sekolah umumnya diperuntukkan bagi siswa-siswa sekolah di waktu pagi yang belajar di SD, SMP dan SMA. Siswa-siswa yang belajar di madrasah diniyah umumnya menambah pengetahuan agama yang tidak diperoleh di sekolah pagi.

Secara umum lembaga madrasah diniyah menghadapi problem, diantaranya: pertama, ditinjau dari aspek penyelenggaraannya, banyak madrasah diniyah yang kepemilikannya beragam (dibawah organisasi keagamaan, yayasan, milik pribadi, dan pesantren) ternyata hal ini menimbulkan permasalahan terutama berkaitan dengan orientasi dan kepentingan. Kedua, kuantitas madrasah diniyah yang tidak diimbangi dengan kualitas SDM (pengelola maupun pengajar). Ketiga, hambatan psikologis, karena merasa sebagai pemilik atau pendiri yang membina madrasah sejak awal, sebagai pengelola (tokoh agama, organisasi keagamaan, dan yayasan) tidak mudah menerima perubahan yang datang dari luar, termasuk dari pemerintah (el-Saha: 83-86)

\section{b. Aspek Manajemen}

Pelaksanaan manajemen di madrasah Diniyah secara umum belum dapat dikatakan maksimal. Ada beberapa kendala yang membuat manajemen di suatu madrasah tidak terkelola dengan baik. 
Ketidakjelasan dalam pemisahan kepemimpinan dengan tenaga pendidik. Adanya tumpang tindih dalam menjalankan kewenangan, sehingga terkadang tugas kepala sekolah merangkap pengelola keuangan dan lain-lain. Mekenisme perekrutan tenaga pendidik dan kependidikan yang tidak professional, sehingga pengelolaan lembaga dan pelaksanaan pembelajaran menjadi carut marut. Hal ini tentunya berimbas pada kualitas pembelajaran di madrasah sehingga berdampak pada berkurangnya jumlah siswa atau peminat yang belajar.

\section{c. Tenaga Pengajar}

Secara konseptual bahwa menjadi guru dituntut adanya keikhlasan, termasuk jika tidak digaji sekalipun. Pada awalnya munculnya madrasah Diniyah di Indonesia adalah adanya kesadaran dari masyarakat akan pentingnya pendidikan agama. Oleh karena itu guru madrasah diniyah pun merasa terpanggil untuk mengajar dengan suka rela tanpa berfikir akan gaji. Namun seiring perkembangan zaman, masyarakat masih menganggap bahwa eksistensi madrasah diniyah bagi masyarakat Islam masih penting, maka pengelola lembaga ini mencoba untuk memberikan insentif yang sessuai.

Membincang persoalan insentif (bisyaroh) bagi guru madrasah diniyah sampai saat ini masih belum dapat dikatakan "layak". Karena prinsip keikhlasan itulah yang terkadang membuat pengelola madrasah diniyah dengan ukuran keikhlasan tersebut. Yang terpenting dari adanya guru di madrasah diniyah adanya kemauan untuk mengajar siswa sesuai dengan keilmuannya. Latar belakang pendidikan terkadang tidak menjadi prioritas. Terkadang pihak pengelola beranggapan yang terpenting lagi adalah ada siswa ada guru atau sebaliknya sehingga madrasah tersebut tidak mati suri. Tenaga pendidik atau pengajar di madrasah diniyah memiliki latar belakang yang beragam, seperti Madrasah aliyah, pesantren dan lain-lain dengan latar belakang pekerjaan tetapnya juga beragam (petani, tukang kayu, takmir dan lain-lain). Sehingga yang mengajar siswa di madrasah diniyah dapat dikatakan "siapa yang mau dan sempat”. Pekerjaan guru madrasah diniyah sering disebut pekerjaan sampingan atau dalam istilah jawa biasa disebut samben. 
Profesionalitas bagi guru madrasah diniyah bukan menjadi hal yang utama. Pada dasarnya keadaan dan kemampuan guru sesungguhnya tidak perlu menjadi hal yang perlu diperhatikan, sebab guru dituntut untuk memiliki kemampuan dalam segala hal yang berkenaan pelaksanaan pendidikan dan pengajaran. Kalau pada suatu saat guru memiliki kekurangan, dituntut untuk segera belajar atau meningkatkan dirinya. Bagi guru yang masih memiliki pengalaman yang sedikit, kekurangan kemampuan pada guru tersebut perlu diperhatikan (Ibrahim, 1986: 65).

\section{d. Keadaan Siswa}

Minat orang tua untuk meyekolahkan anaknya sangat rendah. Hal ini dilandasi pemikiran bahwa pendidikan untuk anak-anak cukup di sekolah pagi saja. Selain itu padatnya kegiatan ekstrakurikuler di sekolah membuat prioritas tetap untuk kegiatan di sekolah pagi. Apalagi sekarang marak sekolah dengan konsep "terpadu". Konsep yang memadukan kurikulum mata pelajaran agama dengan kurikulum mata pelajaran umum, dengan durasi waktu sampai jam 15.00. Fenomena inilah yang membuat keadaan siswa di madrasah diniyah semakin berkurang.

\section{e. Pendanaan}

Pendanaan di madrasah diniyah sepenuhnya umumnya langsung dikelola oleh penyelenggara lembaga pendidikan. Dana tersebut berasal dari setidaknya dari empat sumber yaitu 1) uang sekolah (SPP) 2) biaya pendaftaran, ujian , 3) donasi dari dermawan dan masyarakat yang peduli dengan madrasah diniyah, dan 4) zakat, infak dan sadakah. Penggunaan dan pengelolaan dana di madrasah diniyah untuk operasional madrasah termasuk gaji guru dan karyawan. Adapun pendanaan yang berkkaitan dengan fasilitas dan sarana prasarana terkadang tidak terfikirkan karana minimnya dana.

\section{f. Sarana dan Prasarana}

Fasilitas di madrasah diniyah, pada umumnya tidak seideal keadaanya di sekolah (pagi). Keadaannya sederhana, yang terpenting adalah adanya tempat atau ruang belajar, papan tulis dan tempat duduk, sehingga pembelajaran tetap berjalan. Jika ditinjau dari awal keberadaanya, maka madrasah diniyah berada di masjid. Ketika sudah memiliki gedung sendiri maka lokasi belajar dipindah. 
Sampai sekarang pembelajaran mmadrasah diniyah sudah tidak dilaksanakan di masjid.

Madrasah Diniyah yang memiliki gedung dan sarana prasarana sendiri hanyalah madrasah yang ada dilokasi pesantren. Hal ini dapat dimaklumi karena keterbatasan yang ada di madrasah diniyah (Ibrahim, 1986: 93-95).

\section{g. Kegiatan evaluasi Pembelajaran}

Setiap pempelajaran yang dilaksanakan di sekolah, maka harus diberengi dengan adanya evaluasi belajar. Hal ini sebagai tolok ukur keberhasilan siswa dalam belajar. Walaupun memang dalam pelaksanaan di setiap satuan pendidikan berbeda. Dalam kurikulum yang diberlakukan di sekolah maupun madrasah selalu menggunakan evaluasi. Meskipun madrasah diniyah dikategorikan dalam pendidikan tradisional mnamun tetap saja diberlakukan evaluasi dengan istilah imtihan. Evaluasi ini sebagai ukuran prestasi siswa.

\section{h. Kurikulum Madrasah Diniyah}

Kurikulum adalah rancangan pembelajaran yang harus ada di setiap lembaga pendidikan, termasuk di madrasah diniyah. Pengelola dalam hal ini kepala sekolah maupun guru di madrasah diniyah masih belum memahami urgensi keberadaan kurikulum.

Madrasah Diniyah adalah bagian terpadu dari system pendidikan nasional yang diselenggarakan pada jalur pendidikan luar sekolah untuk memenuhi hasrat masyarakat tentang pendidikan agama. "Penyelenggaraan pendidikan diluar sekolah boleh dilembagakan dan boleuh tidak dilembagakan”. Dengan jenis "pendidikan Umum” (UU Pendidikan dan PP no 73 tahun 1991 pada pasal 1 ayat 1 dan pasal 3. ayat.1). Hal ini tentunya termasuk masdrasah diniyah.

Dalam PP 73, Pasal 22 ayat 3 disebutkan bahwa Madarsah diniyah termasuk kelompok pendidikan keagamaan jalur luar sekolah yang dilembagakan dan bertujuan untuk mempersiapkan peserta didik menguasai pengetahuan agama Islam, yang dibina oleh Menteri Agama. Oleh karena itu, selanjutnya Menteri Agama d/h Direktorat Jenderal Pembinaan Kelembagaan Agama Islam menetapkan Kurikulum Madrasah Diniyah dalam rangka membantu masyarakat 
mencapai tujuan pendidikan yang terarah, sistematis dan terstruktur. Namun demikian, masyarakat tetap memiliki keleluasaan dalam mengembangkan isi pendidikan, pendekatan dan muatan kurikulum sesuai dengan analisis kebutuhan (need assessment).

Sepanjang perjalanan sejarah madrasah diniyah mengalami dinamika, sehingga terjadi pasang surut dalam perkembangannya. Ada beberapa kelemahan dalam penerapan kurikulum yang selama ini masih diberlakukan di madrasah diniyah, dan kurang sesuai, diantaranya; 1) belum ada kurikulum tertulis, artinya tidak ada penduan dalam penerapan kurikulum. Namuntujuan pembelajaran hanya memberi bekal kepada siswa dalam membaca al-Quran dan kitab kurning. 2) kurikulum hanya dipahami sebatas pada penggunaan buku ajar yang dijadikan acuan belajar tidak adan standar kompetensi maupun kompetensi dasar. Guru dalam mengajar tidak menggunakan target belajar tertentu dengan berpedoman pada RPP. 3) Pendekatan kurikulum yang digunakan adalah menamatkan buku secara berurutan dan berjenjang. Bahkan ada motivasi belajar terhadap kitab-kitab tertentu dengan tujuan mencari berkah dari buku yang dipelajari. Dan 4) Ketersediaan SDM yang kurang kompeten, sehingga pembelajaran bukan didasarkan pada kebutuhan siswa namun lebih didasarkan pada kewajiban. Artinya adanya anggapan guru ketika sudah mengajar maka akan gugur kewajibanya.

Kurikulum Madrasah diniyah telah mengalami perubahan. Hal ini bertujuan memenuhi kebutuhan masyarakat dan tujuan pembangunan nasional. Tahun 1983 telah disusun kurikulum Madrasah Diniyah sesuai dengan keputusan menteri Agama nomor 3 tahun 1983 yang menjadi 3 tingkatan, yaitu diniyah awaliyah, diniyah wustho dan diniyah ulya.

Sebagaimana dijelaskan oleh Ibrahim (1986: 93-95), pada tahun 1991 kurikulum Madrasah Diniyah dikembangkan menjadi tiga tipe, yaitu:

1) Tipe A berfungsi membantu dan menyempurnakan penyampaian tema sentral pendidikan agama pada sekolah umum terutama dalam hal praktek dan latihan ibadah serta membaca al-Quran.

2) Tipe B berfungsi meningkatkan pengetahuan agama Islam 
sehingga setara dengan madrasah ini lebih berorientasi pada kurikulum madrasah ibtidaiyah, madrasah tsanawiyah dan madrasah aliyah.

3) Tipe $C$ berfungsi untuk pendalaman agama, dengan sistem pondok pesantren.

Sedangkan ditinjau dari segi keberadaannya, sebagaimana penjelasan dalam TP 73 Pasal 2 ayat 2 s.d 3, Madrasah Diniyah memiliki beberapa tujuan diantaranya: 1) Melayani warga belajar dapat tumbuh dan berkembangn sedini mungkin dan sepanjang hayatnya guna meningkatkan martabat dan mutu kehidupanya. 2) Membina warga belajar agar memiliki pengetahuan, keterampilan dan sikap mental yang diperluakan untuk mengembangkan diri, bekerja mencari nafkah atau melanjutkan ketingkat dan/atau jenjang yang lebih tinggi, dan 3) Memenuhi kebutuhan belajar masyarakat yang tidak dapat dipenuhi dalam jalur pendidikan sekolah.

Kurikulum Madrasah Diniyah pada dasarnya bersifat fleksibel dan akomodatif. Oleh karena itu, pengembangannya dapat dilakukan oleh Departemen Agama Pusat Kantor Wilayah Propinsi dan Kantor Departemen Agama Kabupaten/Kotamadya atau oleh pengelola kegiatan pendidikan sendiri. Prinsip pokok untuk mengembangkan tersebut ialah tidak menyalahi aturan perundang-undangan yang berlaku tentang pendidikan secara umum, peraturan pemerintah, keputusan Menteri Agama dan kebijakan lainnya yang berkaitan dengan penyelenggaraan madrasah diniyah.

\section{i. Mejaga Eksistensi Madrasah Diniyah}

Masyarakat Islam tentunya tidak ingin melihat keberadaan madrasah diniyah sebagai sebuah lembaga yang keberadaannya hanya sebagai pelengkap. Perlu pemikiran yang cukup brilian agar keberadaannya tetap menjadi bagian dari kebutuhan masyarakat, sebagaimana awal kemunculannya di Indonesia. Eksistensinya perlu dijaga dan dikembangkan.

Ada beberapa langkah yang perlu dijadikan langkah taktis untuk mempertahankan eksistensi madrasah diniyah, diantaranya; 1) Penyelenggaraan dan pembekalan bagi guru-guru madrasah diniyah berkaitan tentang materi, metode dan strategi pembelajaran yang disesuaikan dengan kompetensi dankarakteristik daerah 
masing-masing. 2) Perlu adanya distribusi buku-buku pelajaran standar madrasah diniyah untuk wilayah-wilayah yang tidak atau belum memiliki kurikulum standar. 3) Penyelenggaraan pengawasan pembinaan, dan pendampingan bagi setiap madrasah diniyah di berbagai wilayah meliputi manajemen, pembelajaran dan lain-lain. dan 4) membangun kerjasama dengan pemerintahan-pemerintahan local, terutama berkaitan dengan alokasi dana. Kerjasama dengan pemerintah local diharapkan minimal dapat membentu dalam hal pendanaan dan pemenuhan sarana dan prasarana kegiatan pembelajaran.

Selain itu, menurut Amin (2006: 102-103) untuk menjaga eksistensi madrasah diniyah maka perlu juga pemikiran untuk mewujudkan madasah yang ideal, diantaranya:

1. Integralisasi sistem pendidikan mdrasah diniyah ke dalam sistem pendidikan formal pesantren.

2. Penerapan manajemen pendidikan secara baik dalam madrasah diniyah.

3. Sistem pembelajaran yang digunakan harus mengacu pada pola pembelajaran yang terpola dan berpedoman kepada kurikum.

4. Melengkapi madrasah diniyah dengan fasilitas belajar terutama media pendidikan yang sesuai.

\section{Simpulan}

Dalam PP 73, Pasal 22 ayat 3 disebutkan bahwa Madrasah diniyah termasuk kelompok pendidikan keagamaan jalur luar sekolah yang dilembagakan dan bertujuan untuk mempersiapkan peserta didik menguasai pengetahuan agama Islam, yang dibina oleh Menteri Agama. Sepanjang perjalanan sejarah madrasah diniyah mengalami dinamika, sehingga terjadi pasang surut dalam perkembangannya.

Ada beberapa kelemahan dalam penerapan kurikulum yang selama ini masih diberlakukan di madrasah diniyah, dan kurang sesuai, diantaranya: 1) belum ada kurikulum tertulis, 2) kurikulum hanya dipahami sebatas pada penggunaan buku ajar yang dijadikan acuan belajar tidak adan standar kompetensi maupun kompetensi dasar. 3) Pendekatan kurikulum yang digunakan adalah menamatkan 
buku secara berurutan dan berjenjang. dan 4) Ketersediaan SDM yang kurang kompeten.

Oleh karena itu untuk mempertahankan eksistensi Madrasah diniyah agar tetap diminati masyarakat maka perlu ada strategistrategi diantaranya: 1) Penyelenggaraan dan pembekalan bagi guruguru madrasah diniyah berkaitan tentang materi, metode dan strategi pembelajaran yang disesuaikan dengan kompetensi dankarakteristik daerah masing-masing. 2) Perlu adanya distribusi buku-buku pelajaran standar madrasah diniyah untuk wilayah-wilayah yang tidak atau belum memiliki kurikulum standar. 3) Penyelenggaraan pengawasan pembinaan, dan pendampingan bagi setiap madrasah diniyah di berbagai wilayah meliputi manajemen, pembelajaran dan lain-lain. dan 4) membangun kerjasama dengan pemerintahanpemerintahan lokal, terutama berkaitan dengan alokasi dana. 


\section{Daftar Pustaka}

Abdushoma, Adib. 2006. Mencari Tipologi Format Pendidikan Ideal. Jakarta: Pustaka Pelajar.

Amin, Headri. 2006. Peningkatan Mutu Terpadu Pesantren dan Madrasah Diniyah. Jakarta: Diva Pustaka.

Arief, Arman. 2002. Pengantar Ilmu dan Metodologi Pendidikan Islam. Jakarta: Ciputat Pers.

Daulay, Haidar Putra. 2001. Historisitas dan Efisiensi Pesantren sekolah dan Madrasah. Yogyakarta: PT Tiara Wacana.

Hasbullah. 1999. Kapita selekta Pendidikan Islam. Jakrta: PT Raja Grafindo Persada.

Ibrahim. 1986. Perencanaan Pengajaran. Jakarta: Rineka Cipta.

Khozin, Manajemen Pemberdayaan madrasah, Malang: UMM Press, 2006

PP No 55 pasal 15-16 tahun 2007, Tentang Pendidikan Agama dan Kegamaan.

Saha, M. Ishom. 2005. Dinamika Madrasah Diniyah di Indonesia Menelusuri AkarSejarah Pendidikan Formal. Jakarta: Pustaka Mutiara.

Suharto, Toto. 2005. Lembaga Pendidikan dan Modernisasi. Yogyakarta: Global Pustaka Utama.

Tim penyusun. 1999. Kamus Besar Bahasa Indonesia. Jakarta: Balai Pustaka.

Uhbiyati, Nur. Ilmu Pendidikan Islam, Bandung: Pustaka Setia. 2005.

UU Pendidikan dan PP no 73 tahun 1991 pada pasal 1 ayat 1 dan pasal 3. 
Nuriyatun Nizah 